\title{
Community based tourism in Nagari Lawang, West Sumatera: Participation Approach Analysis
}

\author{
Wempie Yuliane ${ }^{1 *}$, Vivi Ukhwatul $\mathrm{KM}^{2}$, and Moh. Sholeh ${ }^{3,4}$ \\ ${ }^{1}$ Faculty of Economics, University of Andalas Padang \\ ${ }^{2}$ Research and Development Agency of West Sumatera \\ ${ }^{3}$ Faculty of Fisheries and Marine Science, Brawijaya University \\ ${ }^{4}$ Departement of Aquatic Resource Management, Trunojoyo University Malang, Indonesia
}

\begin{abstract}
Community-Based Tourism (CBT) is one of the emerging tourism models in the last few decades as an alternative to mass tourism in all over the world. This can be categorized as sustainable tourism because it includes local people participation, and conservation. Lawang Village (known as Nagari Lawang) is one of the village in the West Sumatera Indonesia that has been trying CBT since 2012 with rich potential tourisms: culture, nature, adventure, traditional culinary, and handycraft. However, this is not as easy for CBT conducted sucessfully benefiting stakeholders because of two major dominated private-owned tourism objects. Initally the CBT was promoted and initiated by one of the owner of private tourism, now it is just has lost its power and continuity and faced problems such as lack of human resources, loss global promotion, and finally the collaps of many homestays that have been designed before. However some local economic activities like traditional beverage production called "tebu lawang" and traditional gift shop are still running well. The purposes of this study are to find the community participation level in CBT Lawang and to determine the proper policy to recover CBT's profitable business. To achieve the study purposes this research used qualitative research design through Focus Group Disucssion and SWOT Analysis. Primary data were collected through observation, interview, and focus group discussion (FGD). The study results shows that based on Arnstein Participation Theory, CBT Lawang lies on the second step of participation where local people support tourism but has no access to resolve problems. Based on the SWOT analysis, the local government rules needed to regulate private tourism object in order to evade competition and to strengthen cooperation with CBT.
\end{abstract}

\section{Introduction}

Tourism sector in West Sumatera Province based on Central Bureau Statistics became the second highest growth among the other sectors in West Sumatera. The average growth of tourism activity which is represented by accomodation and food service activities, the last five year (2015-2019) is in average, 8.31 percents while regional economics growth is in average 5.31 percents. Nevertheless the contribution to regional economy is still small around 1 percent, but the growth and the linkage with other sector such transportation, communication, industry and agriculture, make tourism sector in West Sumatera priority. Communication sector depicted the highest economic growth, 8.91 percents and transport has 1,68 percents higher economic growth than regional growth.

Community Based Tourism (CBT) is kind of tourism that link natural, social and culture resources through local communities as a complementer activities which is based parimarily on agriculture and livestock farming [1]. As a results, CBT gives benefits to economy, social, culture and environment [2]. But it needs some pre condition, what we call, collaboration process between different public administrations: Non-Governmental
Organisations (NGO), private institutions and local community. Additionally, local communities have some limitations like financial resources, infrastucture or know how, limitations of cultural kind and conflicts between different public administrations [1].

Furthermore, the need of collaboration between CBT-private enterprise-NGO and university-local government is important $[1,3,4]$. CBT can not stand alone on their own feet because most CBT still has lack of capacity [4], insufficient institutional capacity [3,5], and inadequate government intervention as well as private enterprise support [4].

Tourism office of West Sumatera Province has been refocusing on Community Based Tourism (CBT) since 2017. Nevertheless, it has been developing by community and local champion people long time before 2017. Many tourist object based on community arised in the last ten year. The first CBT in West Sumatera is Forum Agrowisata Madani Matur or we can call CBT Lawang as part of it, Agam District, was held in 2012. Secondly, CBT LA Adventure Nyarai, Padang Pariaman District, was held in 2013. Followed by CBT Rantih, Sawahlunto City, in 2015, CBT Kubu Gadang, Padang Panjang City, in 2017, CBT Tungkal Selatan, Pariaman City, in 2018, CBT Kapalo Banda, 50 Kota District, in

\footnotetext{
* Corresponding author: wempie_y@yahoo.com
} 
2018, CBT Simarosok, Agam District, in 2018, and CBT Silokek, Sijunjung District, in 2018. Data from the tourism promotion departement office, majority above new comer tourist destinations still exist until now except CBT Lawang.

As the first CBT in West Sumatera, we would like to have lesson learn why CBT Lawang became less success and is there any prerequisite to improve it. This study limit the investigation into how social CBT through participation of local people in CBT Lawang, regardless other two important factors: economic and environment. Then how to improve the way local people, local government and private enterprises interact with CBT Lawang.

\section{Methodology}

This research method is a qualitative method with descriptive approach and quantitave data collected as data from primary and secondary data source. According to Creswell [6], qualitative research method deal with data collection, analysis, interpretation and report writing. Research activities like purposive sampling, collection of open-ended data, analysis of text or pictures, representation of information in figures and table, and personal interpretation of the findings, are all part of qualitative methodology research. This research was aimed to produce descriptive analysis to determine level of participation of local people in CBT Lawang using participation hierarchy model by Anrstein and then Okazaki specific to community-based tourism model. This research was conducted for six months starting from April-September 2018. Types of data used is primary and secondary data. Primary data collection techniques were conducted by in-depth interviews, focus group discussion, questioner and direct observation. Secondary data sources originated from village government, village potential data (pondes) and Tourism Office of Agam District.

In-dept interviews was conducted to answer the questions related to CBT Matur and CBT Lawang as part of it related to organization, human resources, administrator, financial capacity, and problems arose for continuity of CBT in the long term. Some key person that we had in interview such owner of one private own tourist object that is also local champion of CBT Matur, another administrator of CBT Matur, village government, administrator of CBT Lawang, souvenir entertprise, religious leader, traditional public figure and youth figure.

Questioner and FGD was held at the same time to get information about people perception on tourism and what kind of strategy to have in follow to increase the role of tourism especially generated by local people.

Furthermore, secondary data collection is an information in documents, reports, scientific papers and secondary data sources relevant to this research. Specific data from office district was collected to confirm some information that we already had in the first step primary data collection like tourism district office, sub district office and regional development planning agency and village potential data. Mostly secondary data that we had in this step was to get more information of district government policy and financial support from APBD to tourism of Lawang as private own tourism site, government own tourism site and CBT Lawang. Based on all of primary and secondary data, we used SWOT analysis to have strategy to rectify CBT Lawang performance in the future.

\section{Results and Discussion}

\subsection{CBT Matur and Lawang History}

CBT Lawang held in 2012 as a part CBT Matur or we call Forum Agrowisata Madani in Matur Sub District [7]. As a village (nagari) in Matur Sub District, Nagari Lawang was projected to became a center of nature tourism for its well known tourism object Lawang Park and Puncak Lawang. The existense of these two objects created some businesses related to tourism such as homestay for accomodation, traditional food and home industry souvenir, and traditional baverage, water cane drink, called "tebu lawang". According to the local champion man who has pioneered CBT Matur it has produced higher value added for cane.

Lawang Park and Puncak Lawang are the main tourist object in Lawang owned by private besides other tourist object in Nagari (Village) Lawang such as Tigo Baleh Nan Basa, Green View, Street View which owned by village government and managed by local people and lastly Ambun Tanai owned by district government under district tourism office. Most visitors from Malaysia and domestic, visit Lawang because of scenic of Lake Maninjau, called "negeri di awan". It lies at 2.000 metres above sea level and has cold and windy climate.

The support and participation of the community in the management of Lawang tourism are good enough, that is, there are channels to convey their aspirations even though they cannot solve the existing problems. The Conflict between natural tourism object management (private) with the community is relatively non-existent. However, the level of community participation in CBT has not been optimal so that it has not been able to have a large impact on improving the welfare of the people of Nagari Lawang. This is due to the lack of facilitation from the government to increase human resource capacity, financial and equipment support, regulations and the provision of adequate infrastructure. Issues that have still not been resolved to date are the maintenance of tourism roads, the need for sugar cane refining machine tools, and regulations on permits for managing tourist objects by the private sector.

The synergy between CBT Lawang and the private sector in the past few years has been intensively established when the new CBT Matur was established as the mother of CBT Lawang. However, the current condition of this synergy only occurs at certain moments, where there is some collaboration made between the private sector and CBT Lawang but is still very sporadic by following the request of visitors visiting the Lawang Park attraction. The role of the private sector as investors, promoters and facilitators of 
capacity building for community human resources around tourism objects has not been seen in the development of CBT Lawang.

CBT Lawang organization as a driving force in community-based tourism management, still cannot be said to be active. The majority of management was no longer active due to various reasons. CBT Lawang organization has not been able to provide incentives for management to be involved both full and partime. The absence of capacity building carried out routinely both by the regional government and through partnerships with the private sector or by universities has made the management cadre process not run well. The existence of a driving force in CBT Lawang becomes a very important issue and determines CBT Lawang journey. The driving force for CBT Lawang is West Sumatera tourism activists and also tourism object owner of Lawang Park, private tourism object in Lawang, which is now no longer active in CBT Lawang in particular as well as CBT Matur in general.

Based on Focus Group Discussion arose the role of the government is felt to be still not optimal in the development of CBT Lawang. There are still many problems such as the maintenance of tourism roads whose responsibility is unclear, the completion of the permit management of the Lawang Park tourism object and the lack of facilitation and support both morally and materially for Lawang tourism, especially CBT Lawang from the local government. Furthermore, the development model for CBT Lawang is aimed at increasing the determinants of CBT, starting from community participation, CBT synergy with the private sector, institutions and government support.

\subsection{CBT Lawang Participation}

Phillips and Roberts [8], community participation determined by sustainable interest among local people and institutional (government and local) support to CBT. Nurhudayati [5] explain three elemements for CBT: economy, social and culture. Each element of CBT in Batu Malang has different result: employment, social capital, local organization that determine CBT sustainability.

Based on Arnstein participation, define community partisipation level into three ladders: non participation, degrees of tokenism dan degrees of citizen power. Each level has sub level, manipulation and therapy as part of non participation. Informing, consultation and placation (satisfaction/reconciliation) as sub level of degrees of tokenism. Finally the degrees of citizen power can be categorized into partnership, delegated power and citizen control.

Social capital in CBT is the ultimate goal to develop CBT. Okazaki [9] categorized CBT into four quadrants: (1) Quadrant I, good social capital relation, good government support that link the social capital. Quadrant 1 can be categorized as the best situation in CBT development because social and economic aspects are interconnected; (2) Quadrant II, bad social capital relation but has good government support or can be defned as latent conflict or exlusion. The effort needed to improve this situation is to redistribute resources to exluded groups; (3) Quadrant III, bad social relation and bad government support. This is the worst situation in CBT development process while government needed to participate and facilitate CBT at the same time social partnership needed to be energized; and the last, Quadrant IV, good social capital relation but lack of government support. This situation is named by coping or something that can be substituted by other parties to replace government role like NGO involvement.

CBT Lawang based on category can be determined through some description in the table below:

Table 1. CBT Lawang Descriptive Explanation

\begin{tabular}{|c|c|c|}
\hline No. & Conditions & Criteria \\
\hline \multirow[t]{2}{*}{1.} & \multirow{2}{*}{$\begin{array}{l}\text { High level of } \\
\text { participation: social } \\
\text { relation is good as } \\
\text { well as social } \\
\text { institution. } \\
\text { Relatively low } \\
\text { horizontal / latent } \\
\text { conflict social } \\
\text { instituion. Relatively } \\
\text { low horizontal / } \\
\text { latent conflict }\end{array}$} & $\begin{array}{l}\text { Social institution like } \\
\text { Custom Body } \\
\text { (Kerapadatan Adat } \\
\text { Nagari) appointed as the } \\
\text { rule model in West } \\
\text { Sumatera }\end{array}$ \\
\hline & & $\begin{array}{l}\text { Participation in tourism } \\
\text { activities high but not in } \\
\text { CBT development and } \\
\text { management (planning, } \\
\text { organizing, monitoring } \\
\text { and evaluating) }\end{array}$ \\
\hline \multirow[t]{3}{*}{2.} & \multirow[t]{3}{*}{$\begin{array}{l}\text { Society have a job } \\
\text { related to tourism } \\
\text { and relatively have } \\
\text { more income after } \\
\text { tourism development } \\
\text { exist both as a } \\
\text { worker in private } \\
\text { enterprise and as a } \\
\text { micro enterprise }\end{array}$} & $\begin{array}{l}\text { Economically, } \\
\text { community's involve in } \\
\text { tourism as a worker for } \\
\text { private tourism enterprise } \\
\text { and as a micro related } \\
\text { tourism enterprise for } \\
\text { example as a fruit sellers, } \\
\text { food traders, souvenir } \\
\text { traders and producers, } \\
\text { sugarcane water sellers }\end{array}$ \\
\hline & & $\begin{array}{l}\text { There use to be homestay } \\
\text { project but now left only } \\
\text { one homestay. }\end{array}$ \\
\hline & & $\begin{array}{l}\text { CBT organization does } \\
\text { not run well anymore }\end{array}$ \\
\hline \multirow[t]{3}{*}{3.} & \multirow[t]{3}{*}{$\begin{array}{l}\text { Lack government } \\
\text { asssistance, aid and } \\
\text { support }\end{array}$} & $\begin{array}{l}\text { Local government budget } \\
\text { allocation for tourism site } \\
\text { in } 2018 \text { was given to } \\
\text { other relatively new } \\
\text { tourism site (Banto Royo } \\
\text { dan Pantai Mutiara) }\end{array}$ \\
\hline & & $\begin{array}{l}\text { No assistance for } \\
\text { homestay and CBT } \\
\text { Lawang from technical } \\
\text { side (tourism office) and } \\
\text { organizational } \\
\text { management (cooperative } \\
\text { trade and industryoffice) }\end{array}$ \\
\hline & & $\begin{array}{l}\text { In } 2018 \text {, cooperative trade } \\
\text { and industry office } \\
\text { allocate sugar cane } \\
\text { processing equipment not } \\
\text { for Nagari Lawang as a } \\
\text { main cane producer but } \\
\text { for neighborhood village }\end{array}$ \\
\hline
\end{tabular}

\subsection{SWOT Analysis}

Considering 3 aspects of development CBT: social, economy and environment, based on survey to 30 people as representative of community in Lawang such 
as religious leaders, public figure, youth figure and traditional figure, we can have conclusion that Lawang people do not reject the tourism activity both, by private as well as by community. From social approach, we have a question whether tourism disturb local people live. Two of three does not agree with that statement. Means, they think tourism does not harm local people life. From point of view of local identitiy, value and culture, $60 \%$ agree that tourism does not make local people lost their identity, value and culture. At the same time majority respondent think that tourism makes local lifestyle being preserved (87 \%). From interaction between local people and visitor, more than $80 \%$ feels that visitors respect them and vice versa. Seven of eight people approved tourism create new idea and cooperation among them. And openness to outsider to get involved in their problem is something that has no objection.

Two others criteria, environment and economy have similar result which economy approach has stronger support from respondent with more than $80 \%$ and support for environmental sustainability has $63 \%$ supporter.

From SWOT analysis, we consider the strengths of CBT Lawang as below:

a. Lawang has rich resources like perfect scenic, specific agriculture product (sugar cane)

b. Good cooperation and coordination among stakeholder in the village especially among legislative, yudicative and executive body

c. Enjoy economic growth through tourism activities

d. Start for English Village development

e. Have islamic boarding school for memorizing $\mathrm{Al}$ Qur'an

f. Has an experience to impelement CBT concept through homestay, plow paddy field tourist attraction and learn to cook rendang cusine as one of the best food in the world version CNN.

Beside many strengths that CBT Lawang has, it also has several weaknesses like:

a. Highly dependent on local champion person as driving force for CBT Lawang and probably this local champion has intended to create fake participation

b. Lack local government support to CBT Lawang

c. Synergy and cooperation of CBT Lawang was in difficult situation after releasing from local champion

d. CBT Lawang position in lawang tourism is not well defined

e. Low standard for food and culinary places

f. Lack of Human resource and management development of CBT Lawang

CBT Lawang has opportunities like:

a. The increasing number of CBT in West Sumatera

b. The province government support CBT as the main objective of tourism regional development in West Sumatera

c. The development of ICT as a media communication, promotion and learning.

The Threat that CBT Lawang has faced: a. Annual international and regional event that promote more to private owned tourist object: Lawang Park and Lawang Top

b. Tourism related activity or small business activity based tourism seems do not need the existence of CBT while they can run business without CBT support

c. Authority conflict between province government and district government to maintain tourism road to Lawang Park and Lawang Top

d. A competition with other village to get grant mechinery from local governement in drying and refining cane sugar product

\section{Conclusion and recommendation}

\subsection{Conclusion}

Lesson that we can learn from CBT Lawang as a pioneer of tourism based on community in West Sumatera:

a. CBT Lawang as starter for CBT in West Sumatera has unique condition because unconsciously compete with 2 private owned tourism object, 1 local government tourism object and several tourist object by community or village government.

b. CBT Lawang has no integration among tourism object, tourism activities and all toursim stakeholder.

c. Local participation can be concluded into level that community aspirates and communicates their willingness but relatively unexecutabale .

\subsection{Recommendation}

Finally we have something to learn about CBT development of CBT Lawang and in the future need major correction if we want this local initiative sustain in the long period.

a. Local government should make rules to regulate private tourism object in order to evade competition and to strengthen cooperation with CBT

b. Genuine local participation is a key to obtain sustainability

c. Degree of control is participation indicator that substantiate the sustainability.

d. Fake participation must be eluded in any way: to get government funding and elit interest [10].

\section{References}

1. Guzman, T. Lopez, Canizares, S. Sanchez, P. Victor, J. of Tourism, 6, 1 (2011)

2. Dangi, B. Tek, J. Tazim, An Integrated Approach to "Sustainable Community-Based Tourism". (2016)

3. R. Sugi, Pengembangan Pariwisata Berbasis Masyarakat (Community Based Tourism) di Kabupaten Kulon Progo Daerah Istimewa 
Yogyakarta, (Laporan Penelitian Hibah Bersaing. Universitas Negeri Yogyakarta, 2015)

4. Tolkach, Denis, K. Brian, Strengthening Community-Based Tourism in New ResourceBased Island Nation: Why and How?, Tourism Management, (2014)

5. Nurhidayati, S. Endah, F. Chafid, Jejaring Adminsitrasi Publik, 1(2012)

6. Creswell, W. Jhon, Research Methods: Quliatative, Quantitave and Mix Method Approach, (4 ${ }^{\text {nd }}$ edition. SAGE Publication, 2014)

7. Forum Agrowisata Nagari matur@wordpress.com, accessed on November 3, 2020, at 15.15

8. R. Phillips, R. Sherma, Tourism Planning and Community Development, ( $1^{\text {st }}$ edition. Routledge., 2013)

9. O. Etsako, Journal of Sustainable Tourism, 16, 5 (2008)

10. K. Kalson, Asia Pacific Journal of Tourism Research, 7, 2 (2002) 